\title{
Ionothermal Access to Defined Oligomers of Supertetrahedral Selenido Germanate Clusters
}

\author{
Zhou Wu, Isabell Nußbruch, Simon Nier, and Stefanie Dehnen*
}

Fachbereich Chemie and Wissenschaftliches Zentrum für Materialwissenschaften, PhilippsUniversität Marburg, 35043 Marburg, Germany

\section{Contents:}

1. Single-Crystal X-ray Diffraction (SCXRD) Data

2. Supplementary Crystallographic Figures

3. Powder X-ray Diffraction (PXRD) Data

4. Light-Microscopic Images of the Single Crystals

5. Energy-Dispersive X-ray (EDX) Spectroscopy

6. Electrospray Ionization Mass Spectrometry (ESI-MS)

7. Stability Study of Solutions of the Soluble Compounds

8. Demonstration of the Tyndall Effect

9. Dynamic Light Scattering (DLS)

10. Raman and Optical Absorption Spectroscopy

11. References for the Supporting Information 


\section{Single Crystal X-ray Diffraction (SCXRD) Data}

Table S1. Crystallographic data and refinement parameters for compound $\mathbf{1 .}$

\begin{tabular}{|c|c|}
\hline Chemical formula & $\mathrm{C}_{24} \mathrm{H}_{44} \mathrm{Ge}_{4} \mathrm{~N}_{8} \mathrm{Se}_{10}$ \\
\hline Formula weight & 1524.63 \\
\hline Empirical formula & $\mathrm{C}_{24} \mathrm{H}_{44} \mathrm{Ge}_{4} \mathrm{~N}_{8} \mathrm{Se}_{10}$ \\
\hline Empirical formula weight & 1524.63 \\
\hline Temperature/K & $100(2)$ \\
\hline Crystal system & tetragonal \\
\hline Space group & $P 4_{2} / n$ \\
\hline$a / \AA$ & $13.6752(14)$ \\
\hline$b / \AA$ & $13.6752(14)$ \\
\hline$c / \AA ̊$ & $12.0415(15)$ \\
\hline$\alpha /^{\circ}$ & 90 \\
\hline$\overline{\beta /{ }^{\circ}}$ & 90 \\
\hline$\overline{\gamma / 0}$ & 90 \\
\hline Volume $/ \AA^{3}$ & $2251.9(5)$ \\
\hline$Z$ & 2 \\
\hline$\rho_{\text {calc }} \mathrm{g} / \mathrm{cm}^{3}$ & 2.249 \\
\hline$\mu / \mathrm{mm}^{-1}$ & 10.754 \\
\hline $\mathrm{F}(000)$ & 1424.0 \\
\hline Crystal size $/ \mathrm{mm}^{3}$ & $0.30 \times 0.25 \times 0.14$ \\
\hline Radiation & $\operatorname{MoK} \alpha(\lambda=0.71073)$ \\
\hline $2 \Theta$ range for data collection $/{ }^{\circ}$ & 4.212 to 49.264 \\
\hline Index ranges & $-16 \leq \mathrm{h} \leq 16,-16 \leq \mathrm{k} \leq 16,-14 \leq 1 \leq 12$ \\
\hline Reflections collected & 13684 \\
\hline Independent reflections & $1908\left[R_{\text {int }}=0.0990, R_{\text {sigma }}=0.0567\right]$ \\
\hline Data/restraints/parameters & $1908 / 2 / 102$ \\
\hline Goodness-of-fit on $F^{2}$ & 0.934 \\
\hline Final $R$ indexes $[I \geq 2 \sigma(I)]$ & $R_{1}=0.0381, w R_{2}=0.1013$ \\
\hline Final $R$ indexes [all data] & $R_{1}=0.0693, w R_{2}=0.1112$ \\
\hline Largest diff. peak/hole / e $\AA^{-3}$ & $1.39 /-0.61$ \\
\hline CCDC number & 2116247 \\
\hline
\end{tabular}


Table S2. Crystallographic data and refinement parameters for compound $\mathbf{2 a}$.

\begin{tabular}{|c|c|}
\hline Chemical formula & $\mathrm{C}_{36} \mathrm{H}_{66} \mathrm{Ge}_{8} \mathrm{~N}_{12} \mathrm{Se}_{19}$ \\
\hline Formula weight & 2747.96 \\
\hline Empirical formula $*$ & $\mathrm{C}_{30} \mathrm{H}_{54} \mathrm{Ge}_{8} \mathrm{~N}_{10} \mathrm{Se}_{19}$ \\
\hline Empirical formula weight $*$ & 2635.95 \\
\hline Temperature/K & $100.0(2)$ \\
\hline Crystal system & triclinic \\
\hline Space group & $P \overline{1}$ \\
\hline$a / \AA$ & $10.2607(5)$ \\
\hline$\overline{b / \AA}$ & $17.6852(9)$ \\
\hline$c / \AA \AA$ & $21.9944(11)$ \\
\hline$\alpha / /^{\circ}$ & $100.8887(18)$ \\
\hline$\beta /^{\circ}$ & $95.5998(18)$ \\
\hline$\gamma /{ }^{\circ}$ & $105.2396(18)$ \\
\hline Volume $/ \AA^{3}$ & $3735.5(3)$ \\
\hline$Z$ & 2 \\
\hline$\rho_{\text {calc }} \mathrm{g} / \mathrm{cm}^{3}$ & 2.443 \\
\hline$\mu / \mathrm{mm}^{-1}$ & 12.465 \\
\hline $\mathrm{F}(000)$ & 2412.0 \\
\hline Radiation & $\operatorname{MoK} \alpha(\lambda=0.71073)$ \\
\hline $2 \Theta$ range for data collection $/{ }^{\circ}$ & 4.16 to 50.796 \\
\hline Index ranges & $-12 \leq \mathrm{h} \leq 12,-21 \leq \mathrm{k} \leq 21,-26 \leq 1 \leq 26$ \\
\hline Reflections collected & 75462 \\
\hline Independent reflections & $13817\left[R_{\text {int }}=0.0516, R_{\text {sigma }}=0.0449\right]$ \\
\hline Data/restraints/parameters & $13817 / 75 / 596$ \\
\hline Goodness-of-fit on $F^{2}$ & 1.236 \\
\hline Final $R$ indexes $[I \geq 2 \sigma(I)]$ & $R_{1}=0.0999, w R_{2}=0.1962$ \\
\hline Final $R$ indexes [all data] & $R_{1}=0.1130, w R_{2}=0.2021$ \\
\hline Largest diff. peak/hole / e $\AA^{-3}$ & $3.20 /-2.10$ \\
\hline CCDC number & 2123214 \\
\hline
\end{tabular}

* Different from the chemical formula as heavy disorder of the cations did not allow for a full localization of all of them from the difference Fourier map. In order to avoid impairment of the refinement of the anionic substructures by an incomplete model, the influence of the electron density of some of the counterions' atoms, which could not be localized was detracted from the data by application of the back Fourier transform method using the SQUEEZE routine in PLATON. ${ }^{1}$ The number of electrons withdrawn is $167 \mathrm{e}^{-}$in one void per unit cell, 122 of which can be assigned to the 2 additional counterions per unit cell (à $61 \mathrm{e}^{-}$) that could not be localized. The residual number of withdrawn electrons per unit cell $\left(45 \mathrm{e}^{-}\right)$cannot be assigned to any complete molecule present in this reaction space, but the number is within the error of this routine applied to ionothermal or solvothermal reaction products. 
Table S3. Crystallographic data and refinement parameters for compound $\mathbf{2 b}$.

\begin{tabular}{|c|c|}
\hline Chemical formula & $\mathrm{C}_{36} \mathrm{H}_{66} \mathrm{Ge}_{8} \mathrm{~N}_{12} \mathrm{Se}_{19}$ \\
\hline Chemical formula weight & 2747.96 \\
\hline Empirical formula $*$ & $\mathrm{C}_{24} \mathrm{H}_{43} \mathrm{Ge}_{8} \mathrm{~N}_{8} \mathrm{Se}_{19}$ \\
\hline Empirical formula weight $*$ & 2524.78 \\
\hline Temperature/K & $100(2)$ \\
\hline Crystal system & monoclinic \\
\hline Space group & $P 2_{1} / c$ \\
\hline$a / \AA$ & $22.2060(2)$ \\
\hline$b / \AA$ & $9.5440(1)$ \\
\hline$c / \AA$ & $36.823(4)$ \\
\hline$\alpha / /^{\circ}$ & 90 \\
\hline$\beta /{ }^{\circ}$ & $105.37(9)$ \\
\hline$\gamma /{ }^{\circ}$ & 90 \\
\hline Volume $/ \AA^{3}$ & $7524.8(9)$ \\
\hline$Z$ & 4 \\
\hline$\rho_{\text {calc }} \mathrm{g} / \mathrm{cm}^{3}$ & 2.426 \\
\hline$\mu / \mathrm{mm}^{-1}$ & 14.373 \\
\hline $\mathrm{F}(000)$ & 4580.0 \\
\hline Radiation & $\mathrm{CuK} \alpha(\lambda=1.54186)$ \\
\hline $2 \Theta$ range for data collection $/{ }^{\circ}$ & 5.56 to 152.852 \\
\hline Index ranges & $-27 \leq \mathrm{h} \leq 26,-7 \leq \mathrm{k} \leq 11,-45 \leq 1 \leq 46$ \\
\hline Reflections collected & 143325 \\
\hline Independent reflections & $15777\left[R_{\text {int }}=0.1546, R_{\text {sigma }}=0.0625\right]$ \\
\hline Data/restraints/parameters & $15777 / 370 / 535$ \\
\hline Goodness-of-fit on $F^{2}$ & 1.070 \\
\hline Final $R$ indexes $[I \geq 2 \sigma(I)]$ & $R_{1}=0.0878, w R_{2}=0.2523$ \\
\hline Final $R$ indexes [all data] & $R_{1}=0.1263, w R_{2}=0.2979$ \\
\hline Largest diff. peak/hole / e $\AA^{-3}$ & $1.57 /-1.73$ \\
\hline CCDC number & 2116249 \\
\hline
\end{tabular}

* Different from the chemical formula as heavy disorder of the cations did not allow for a full localization of all of them from the difference Fourier map. In order to avoid impairment of the refinement of the anionic substructures by an incomplete model, the influence of the electron density of some of the counterions' atoms, which could not be localized was detracted from the data by application of the back Fourier transform method using the SQUEEZE routine in PLATON. ${ }^{1}$ The number of electrons withdrawn is $526 \mathrm{e}^{-}$in two voids per unit cell, 488 of which can be assigned to the 8 additional counterions per unit cell (à $61 \mathrm{e}^{-}$) that could not be localized. The residual number of withdrawn electrons per unit cell $\left(38 \mathrm{e}^{-}\right)$cannot be assigned to any complete molecule present in this reaction space, but are within the typical error of this routine. They might, in theory, stem from a heavily disordered DMMP molecule $\left(\mathrm{C}_{6} \mathrm{H}_{13} \mathrm{NO}\right.$, $64 \mathrm{e}^{-}$) that is present in $\sim^{2 / 3}$ of the unit cells. This is not indicated in the formula, however, as it could not be verified by means of experimental techniques. 
Table S4. Crystallographic data and refinement parameters for compound $\mathbf{3 .}$

\begin{tabular}{|c|c|}
\hline Chemical formula & $\mathrm{C}_{48} \mathrm{H}_{88} \mathrm{Ge}_{16} \mathrm{~N}_{16} \mathrm{Se}_{36}$ \\
\hline Formula weight & 4893.34 \\
\hline Empirical formula $*$ & $\mathrm{C}_{24} \mathrm{H}_{44} \mathrm{Ge}_{16} \mathrm{~N}_{8} \mathrm{Se}_{36}$ \\
\hline Empirical formula weight $*$ & 4448.99 \\
\hline Temperature/K & $100(2)$ \\
\hline Crystal system & monoclinic \\
\hline Space group & $C 2 / c$ \\
\hline$a / \AA$ & $20.5265(19)$ \\
\hline$b / \AA$ & $28.744(2)$ \\
\hline$c / \AA ̊$ & $19.720(2)$ \\
\hline$\alpha /^{\circ}$ & 90 \\
\hline$\beta /^{\circ}$ & $94.640(8)$ \\
\hline$\gamma /{ }^{\circ}$ & 90 \\
\hline Volume/ $\AA^{3}$ & $11596.6(18)$ \\
\hline$Z$ & 4 \\
\hline$\overline{\rho_{\text {calc }} \mathrm{g} / \mathrm{cm}^{3}}$ & 2.803 \\
\hline$\mu / \mathrm{mm}^{-1}$ & 15.417 \\
\hline$F(000)$ & 7920.0 \\
\hline Radiation & $\operatorname{MoK} \alpha(\lambda=0.71073)$ \\
\hline $2 \Theta$ range for data collection $/{ }^{\circ}$ & 3.098 to 53 \\
\hline Index ranges & $-22 \leq \mathrm{h} \leq 21,-30 \leq \mathrm{k} \leq 30,-21 \leq 1 \leq 21$ \\
\hline Reflections collected & 32924 \\
\hline Independent reflections & $7582\left[R_{\text {int }}=0.1695, R_{\text {sigma }}=0.1243\right]$ \\
\hline Data/restraints/parameters & $7582 / 85 / 379$ \\
\hline Goodness-of-fit on $F^{2}$ & 0.913 \\
\hline Final $R$ indexes $[I \geq 2 \sigma(I)]$ & $R_{1}=0.0592, w R_{2}=0.1264$ \\
\hline Final $R$ indexes [all data] & $R_{1}=0.1384, w R_{2}=0.1534$ \\
\hline Largest diff. peak/hole / e $\AA^{-3}$ & $1.36 /-0.87$ \\
\hline CCDC number & 2116250 \\
\hline
\end{tabular}

* Different from the chemical formula as heavy disorder of the cations did not allow for a full localization of all of them from the difference Fourier map. In order to avoid impairment of the refinement of the anionic substructures by an incomplete model, the influence of the electron density of some of the counterions' atoms, which could not be localized was detracted from the data by application of the back Fourier transform method using the SQUEEZE routine in PLATON. ${ }^{1}$ The number of electrons withdrawn is $1095 \mathrm{e}^{-}$in one void per unit cell, 976 of which can be assigned to the 16 additional counterions per unit cell (à $61 \mathrm{e}^{-}$) that could not be localized. The residual number of withdrawn electrons per unit cell (119 $\left.\mathrm{e}^{-}\right)$might, in theory, stem from $\sim 2$ heavily disordered DMMP molecules $\left(\mathrm{C}_{6} \mathrm{H}_{13} \mathrm{NO}, 64 \mathrm{e}^{-}\right)$per unit cell. This is not indicated in the formula, however, as it could not be verified by means of experimental techniques. 
Table S5. Crystallographic data and refinement parameters for compound 4.

\begin{tabular}{|c|c|}
\hline Chemical formula & $\mathrm{C}_{72} \mathrm{H}_{132} \mathrm{Ge}_{24} \mathrm{~N}_{24} \mathrm{Se}_{54}$ \\
\hline Formula weight & 7340.01 \\
\hline Empirical formula $*$ & $\mathrm{C}_{48} \mathrm{Ge}_{24} \mathrm{~N}_{16} \mathrm{Se}_{54}$ \\
\hline Empirical formula weight * & 6807.12 \\
\hline Temperature/K & $150(2)$ \\
\hline Crystal system & monoclinic \\
\hline Space group & $P 21 / n$ \\
\hline$a / \AA$ & $14.8339(11)$ \\
\hline$b / \AA$ & $30.6469(17)$ \\
\hline$c / \AA ̊$ & $20.4654(16)$ \\
\hline$\alpha /^{\circ}$ & 90 \\
\hline$\beta /^{\circ}$ & $107.603(6)$ \\
\hline$\gamma /{ }^{\circ}$ & 90 \\
\hline Volume $/ \AA^{3}$ & $8868.2(11)$ \\
\hline$Z$ & 2 \\
\hline$\rho_{\text {calc }} \mathrm{g} / \mathrm{cm}^{3}$ & 2.749 \\
\hline$\mu / \mathrm{mm}^{-1}$ & 12.090 \\
\hline$F(000)$ & 6672.0 \\
\hline Crystal size $/ \mathrm{mm}^{3}$ & $0.18 \times 0.15 \times 0.10$ \\
\hline Radiation & $\operatorname{GaK} \alpha(\lambda=1.34143)$ \\
\hline $2 \Theta$ range for data collection $/{ }^{\circ}$ & 4.672 to 89.994 \\
\hline Index ranges & $-15 \leq \mathrm{h} \leq 15,-31 \leq \mathrm{k} \leq 32,-11 \leq 1 \leq 21$ \\
\hline Reflections collected & 32408 \\
\hline Independent reflections & $10733\left[R_{\text {int }}=0.1248, R_{\text {sigma }}=0.1999\right]$ \\
\hline Data/restraints/parameters & $10733 / 0 / 352$ \\
\hline Goodness-of-fit on $F^{2}$ & 0.877 \\
\hline Final $R$ indexes $[I \geq 2 \sigma(I)]$ & $R_{1}=0.0656, w R_{2}=0.1487$ \\
\hline Final $R$ indexes [all data] & $R_{1}=0.1737, w R_{2}=0.1663$ \\
\hline Largest diff. peak/hole / e $\AA^{-3}$ & $1.31 /-0.75$ \\
\hline CCDC number & 2116251 \\
\hline
\end{tabular}

* Different from the chemical formula as heavy disorder of the cations did not allow for a full localization of all of them from the difference Fourier map. In order to avoid impairment of the refinement of the anionic substructures by an incomplete model, the influence of the electron density of some of the counterions' atoms, which could not be localized was detracted from the data by application of the back Fourier transform method using the SQUEEZE routine in PLATON. ${ }^{1}$ The number of electrons withdrawn by the solvent mask is $769 \mathrm{e}^{-}$in two voids per unit cell, 488 of which can be assigned to the 8 additional counterions per unit cell (à $61 \mathrm{e}^{-}$) that could not be localized. The residual number of withdrawn electrons per unit cell $\left(281 \mathrm{e}^{-}\right)$might, in theory, stem from (up to) four heavily disordered DMMP molecules $\left(\mathrm{C}_{6} \mathrm{H}_{13} \mathrm{NO}, 64 \mathrm{e}^{-}\right)$per unit cell. This is not indicated in the formula, however, as it could not be verified by means of experimental techniques. 
Table S6. Comparison of bond lengths $(\AA)$ of Ge- $(\mu-\mathrm{Se})$ and Ge-Seterminal for compounds $\mathbf{1}$ - 4 .

\begin{tabular}{lll}
\hline Compound & Ge- $(\mu-\mathrm{Se})$ & Ge-Seterminal \\
\hline $\mathbf{1}$ & $2.3674(12)-2.3771(11)$ & $2.2604(13)$ \\
\hline $\mathbf{2 a}$ & $2.3306(26)-2.4066(27)$ & $2.2449(26)-2.2640(30)$ \\
\hline $\mathbf{2 b}$ & $2.3296(19)-2.4127(21)$ & $2.2388(21)-2.2558(21)$ \\
\hline $\mathbf{3}$ & $2.3288(30)-2.3978(33)$ & $2.2296(35)-2.2425(38)$ \\
\hline $\mathbf{4}$ & $2.3262(38)-2.4064(36)$ & $2.2257(45)-2.2429(42)$ \\
\hline
\end{tabular}

2. Supplementary Crystallographic Figures of Compounds 1, 2a, 2b, 3, and 4

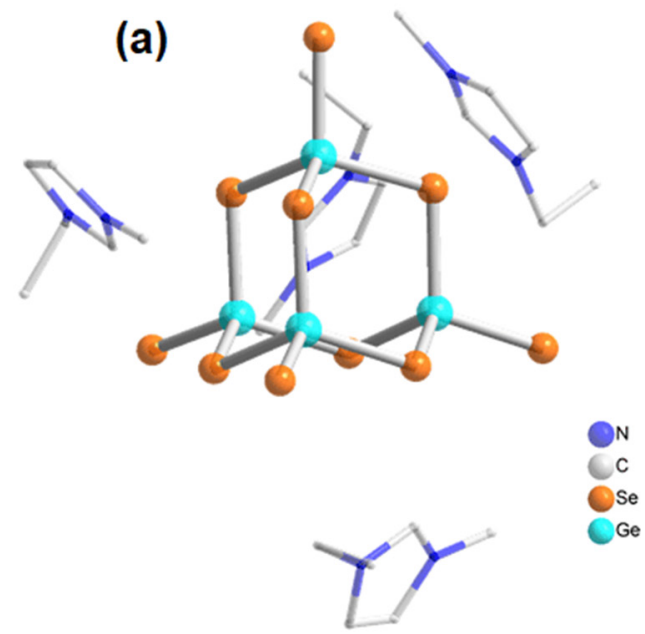

(b)

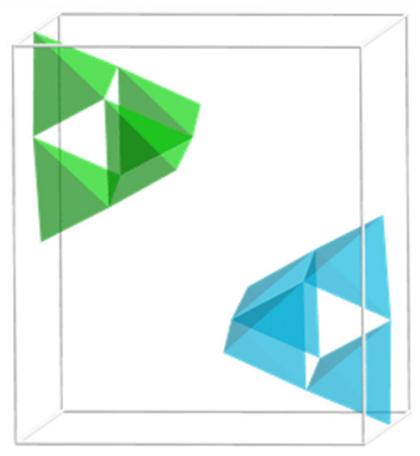

Figure S1. (a) Molecular structure of the cluster anion in compound 1 along with counterions; (b) view of the unit cell of compound 1 (ionic liquid counterions are omitted for clarity).

(a)

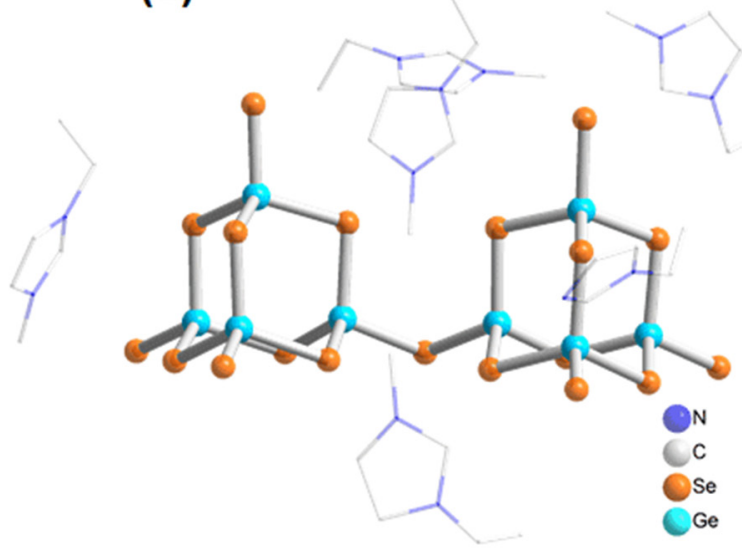

(b)

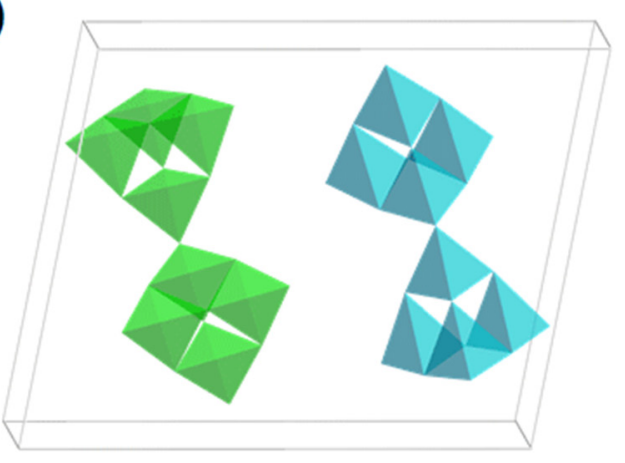

Figure S2. (a) Molecular structure of the cluster anion in compound 2a along with counterions; (b) view of the unit cell of compound $\mathbf{2 a}$ (ionic liquid counterions are omitted for clarity). 


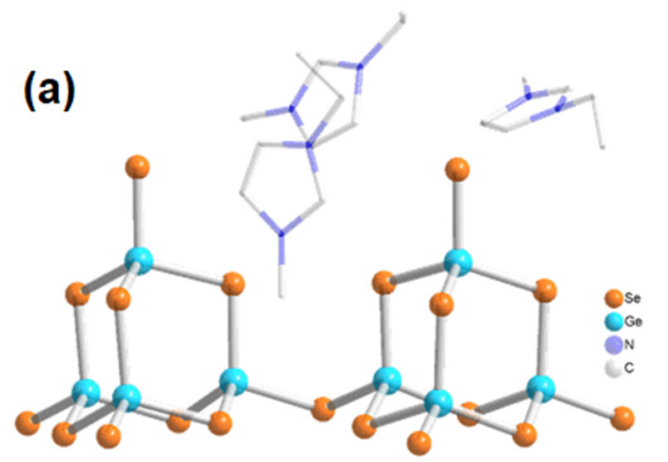

(b)

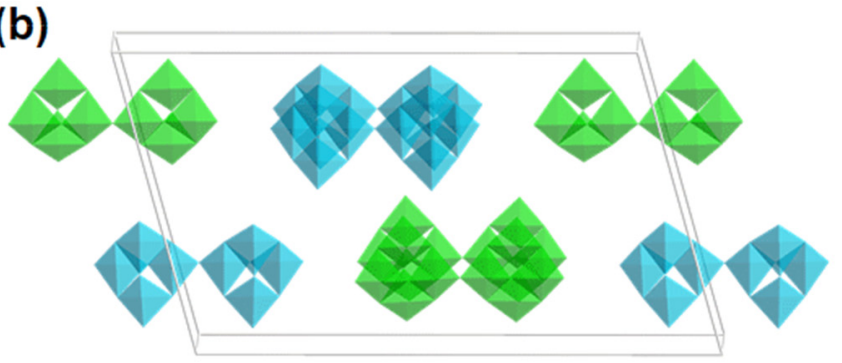

Figure S3. (a) Molecular structure of the cluster anion in compound $\mathbf{2 b}$ along with counterions; (b) view of the unit cell of compound $\mathbf{2 b}$ (ionic liquid counterions are omitted for clarity).

(a)

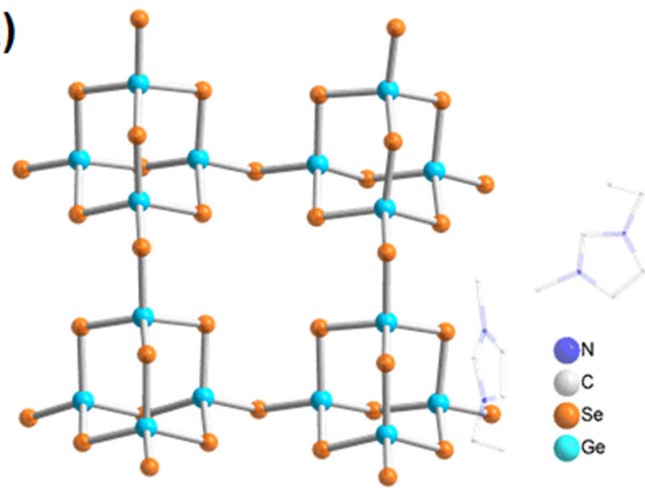

(b)

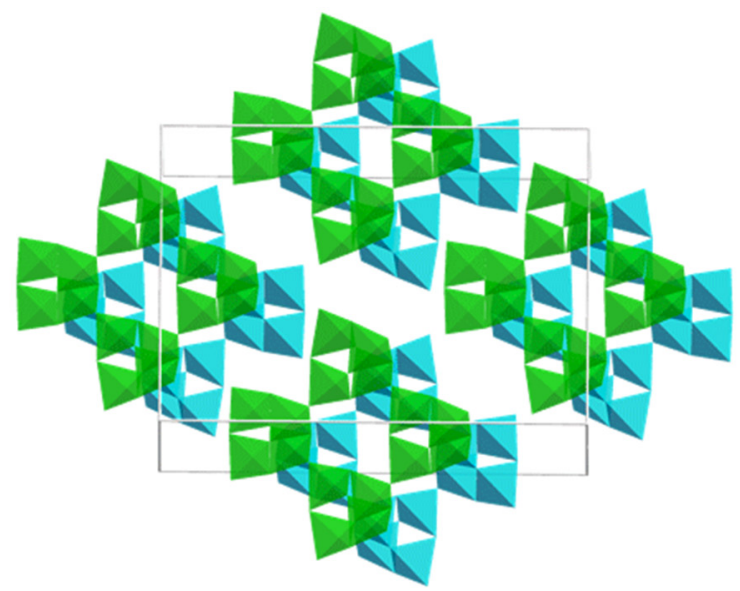

Figure S4. (a) Molecular structure of the cluster anion in compound 3 along with counterions; (b) view of the unit cell of compound $\mathbf{3}$ (ionic liquid counterions are omitted for clarity).

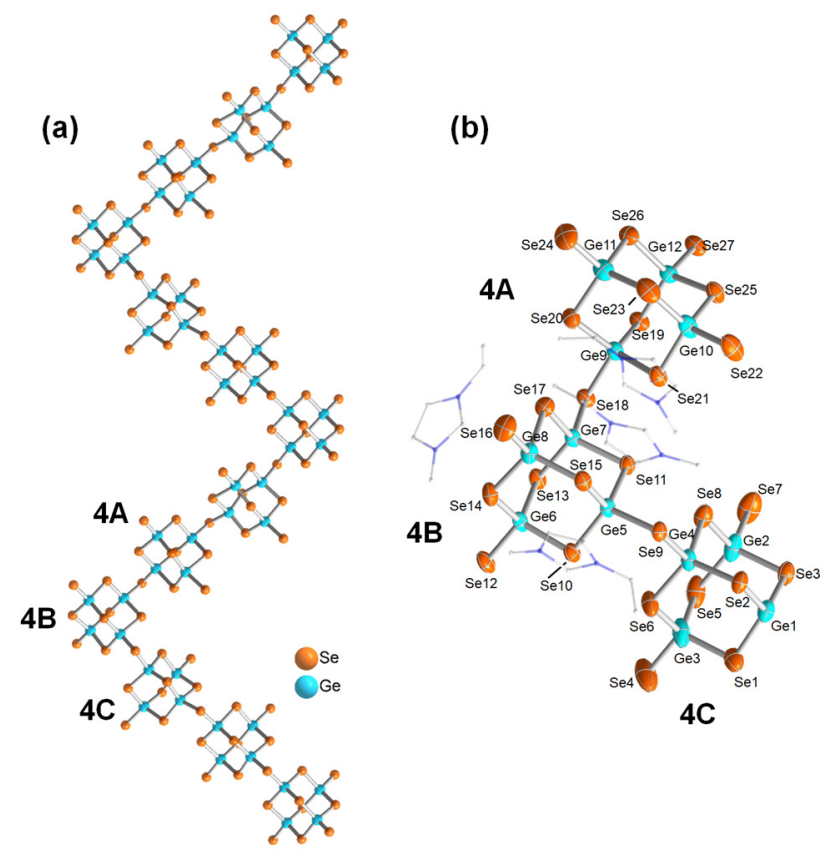

Figure S5. (a) Fragment of the 1D-infinite structure of the cluster anion in compound 4 (ionic liquid counterions are omitted for clarity). (b) The asymmetric unit of compound $\mathbf{4}$ with Ge and Se atoms given as thermal displacement ellipsoids with $50 \%$ probability; counterions are given in wire mode (a part of the counterions could not be determined owing to the high disorder). 
(a)

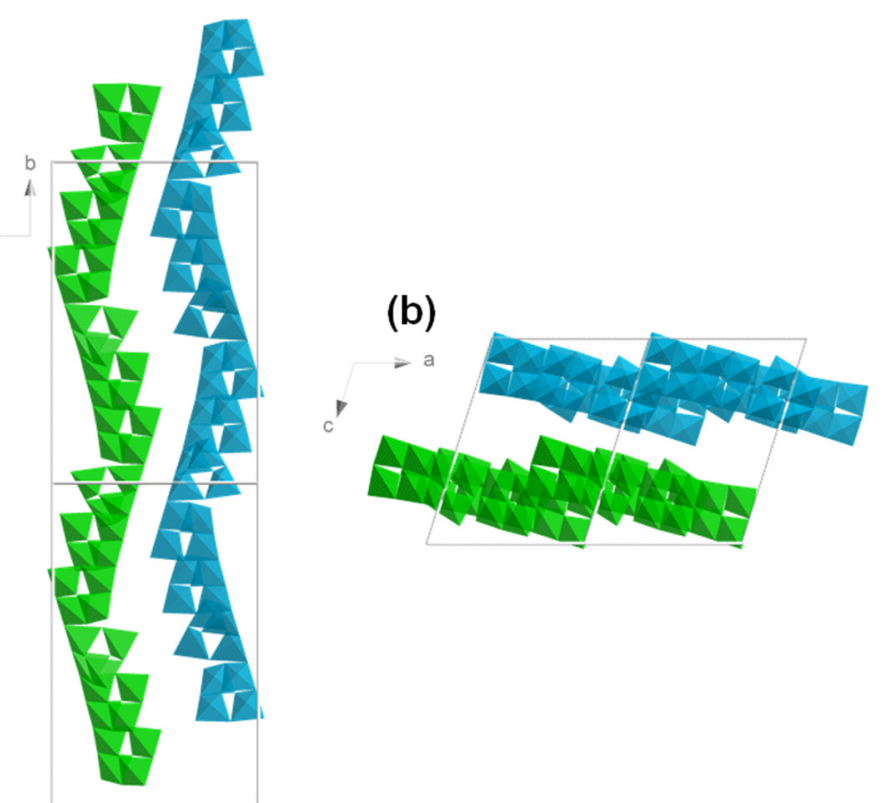

(c)

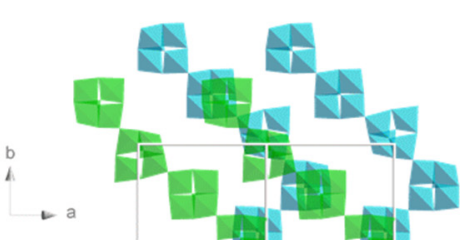

Figure S6. Arrangement of four anionic zig-zag strands in the crystal structure of $\mathbf{4}$, viewed in a $2 \times 2$ supercell from different crystallographic directions, $a(\mathrm{a}), b(\mathrm{~b})$, and $c(\mathrm{c})$.

\section{Powder X-ray Diffraction (PXRD) Data}

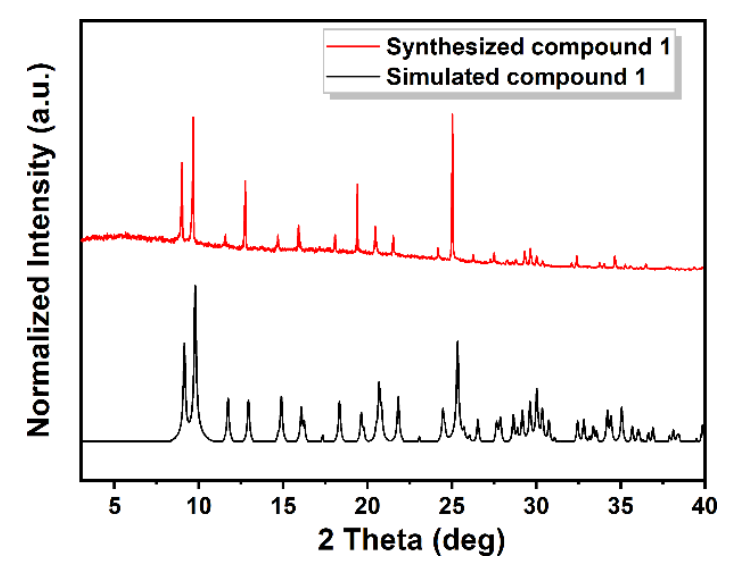

Figure S7. PXRD pattern of as-synthesized compound 1 (top) and simulated one (bottom). Notable differences in the intensities are attributed to texture effects.

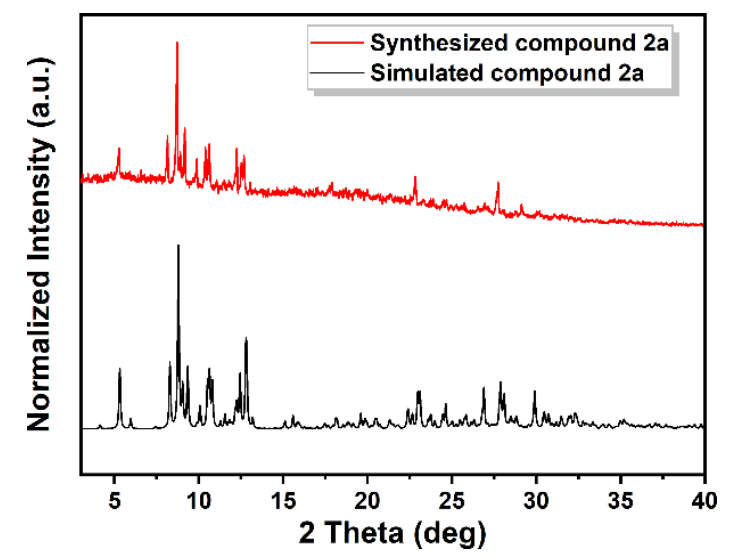

Figure S8. PXRD pattern of as-synthesized compound 2a (top) and simulated one (bottom). 


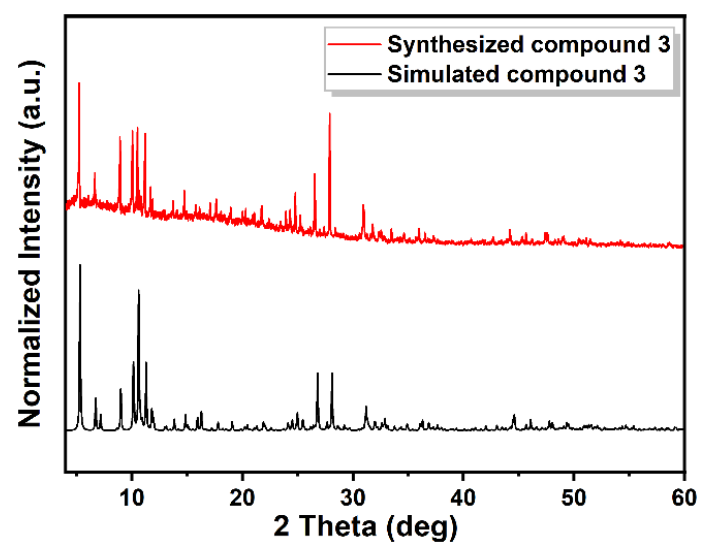

Figure S9. PXRD pattern of as-synthesized compound 3 (top) and simulated one (bottom). Differences in the intensities are attributed to texture effects.

A powder X-ray diagram of $\mathbf{2 b}$ could not be recorded due to the very small yield of the compound; however, the phase purity of its polymorph 2a was confirmed (see Figure S8). Attempts to record a PXRD plot of compound 4 repeatedly failed due to the tendency of the compound to partially decompose during sample preparation.

\section{Light-Microscopic Images of the Single Crystals}

Light microscopic investigation of crystals was performed on the stereo light microscope SteREO Discovery.V8 by Carl Zeiss. The microscope was equipped with a high-intensive coldlight source CL 1500 ECO, an Achromat S 0.63x objective (FWD $107 \mathrm{~mm}$ ), a PL 10x/21 Br ocular, and the microscope camera AxioCam MRc 5 with the camera adapter $60 \mathrm{~N}-\mathrm{C} 2 / 3$ ' $0,63 \mathrm{x}$. The raw photo material was examined by the AxioVision40x64 4.9.1 SP1 software.
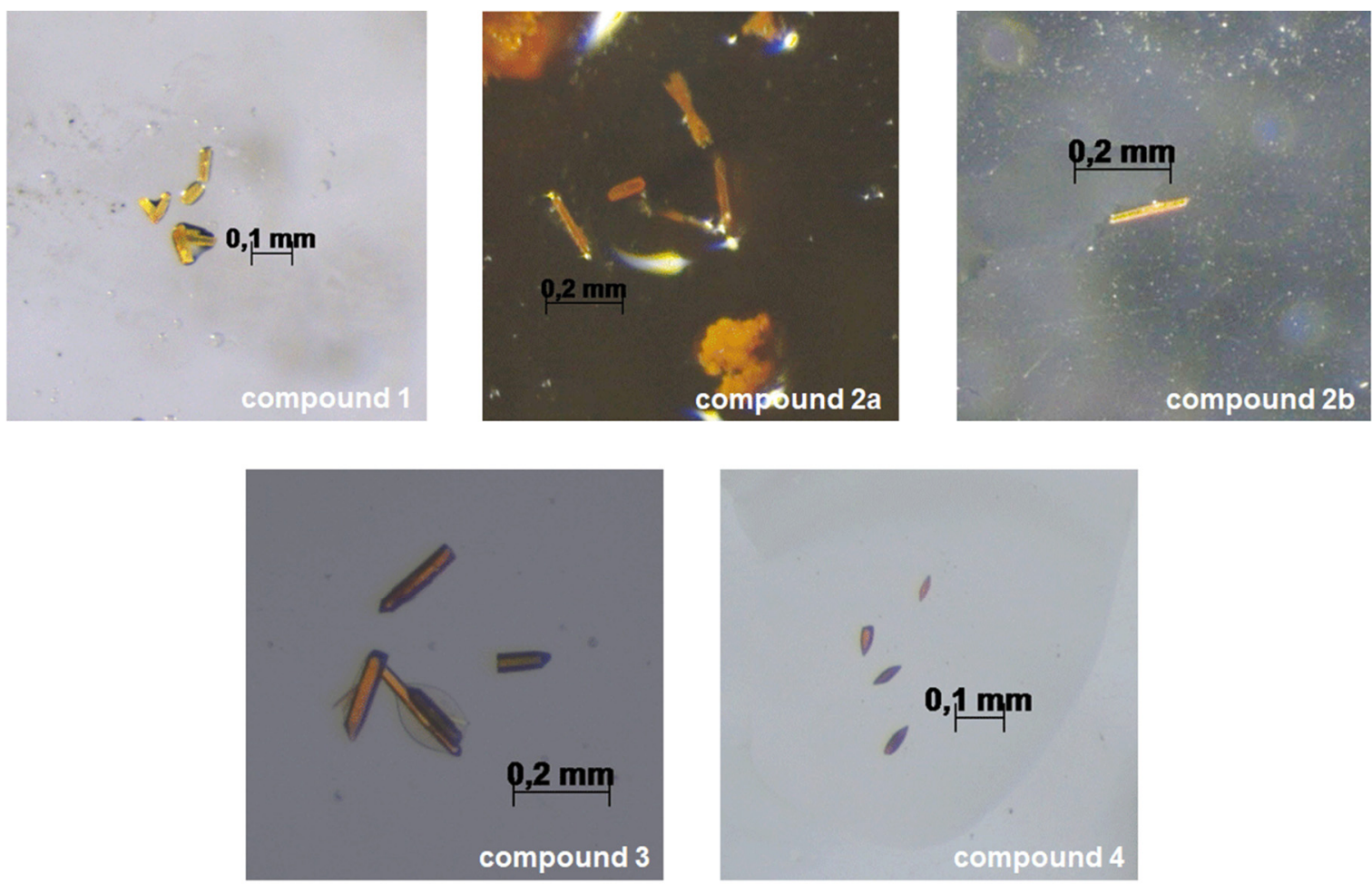

Figure S10. Crystal photographs of compounds 1, 2a, 2b, $\mathbf{3}$ and 4, taken through a light microscope. 


\section{Energy Dispersive X-ray (EDX) Spectroscopy}

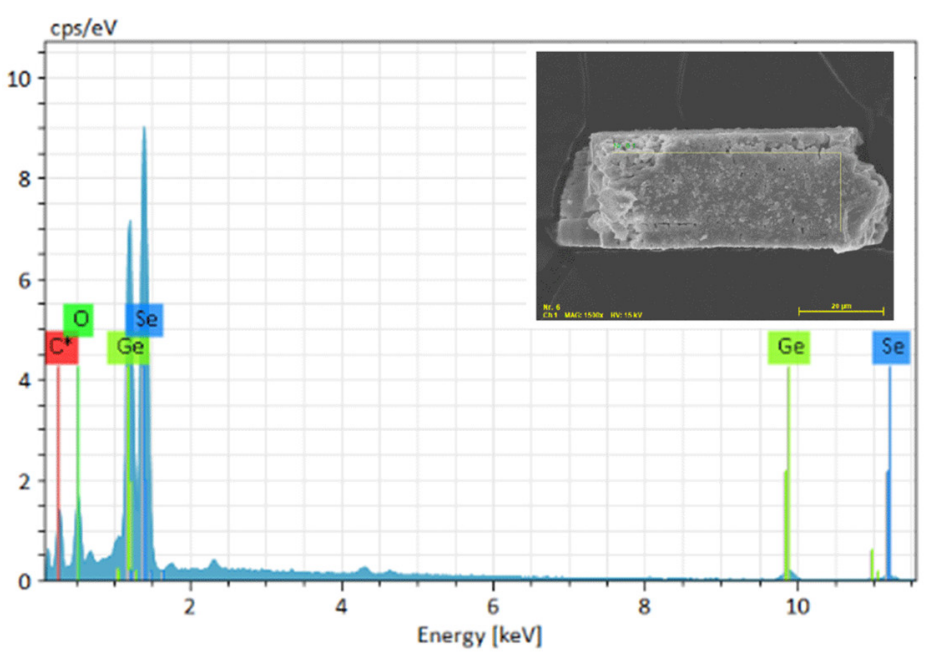

Figure S11. Top: SEM image and EDX spectrum of compound 1. Bottom: result of the EDX analysis of compound 1. Slight differences between calculated and simulated values (well below \pm 1 atom) are caused by the overlap of Ge and Se signals in the EDX spectra.

Table S7. Results of the EDX measurement of compound 1.

\begin{tabular}{llllllll}
\hline Element & $\begin{array}{l}\text { Atomic } \\
\text { No. }\end{array}$ & Netto & $\begin{array}{l}\text { Mass } \\
{[\%]}\end{array}$ & $\begin{array}{l}\text { Atom Cont. } \\
\text { Obs. [\%] }\end{array}$ & $\begin{array}{l}\text { Atom Cont. } \\
\text { Calc. [\%] }\end{array}$ & $\begin{array}{l}\text { Abs. Error } \\
(1 \sigma[w t \%])\end{array}$ & $\begin{array}{l}\text { Rel. Error } \\
(1 \sigma[w t \%])\end{array}$ \\
\hline $\mathrm{Ge}$ & 32 & 37901 & 31.80 & 33.65 & 28.57 & 1.01 & 3.18 \\
\hline $\mathrm{Se}$ & 34 & 60003 & 68.20 & 66.35 & 71.43 & 2.52 & 3.69 \\
\hline
\end{tabular}

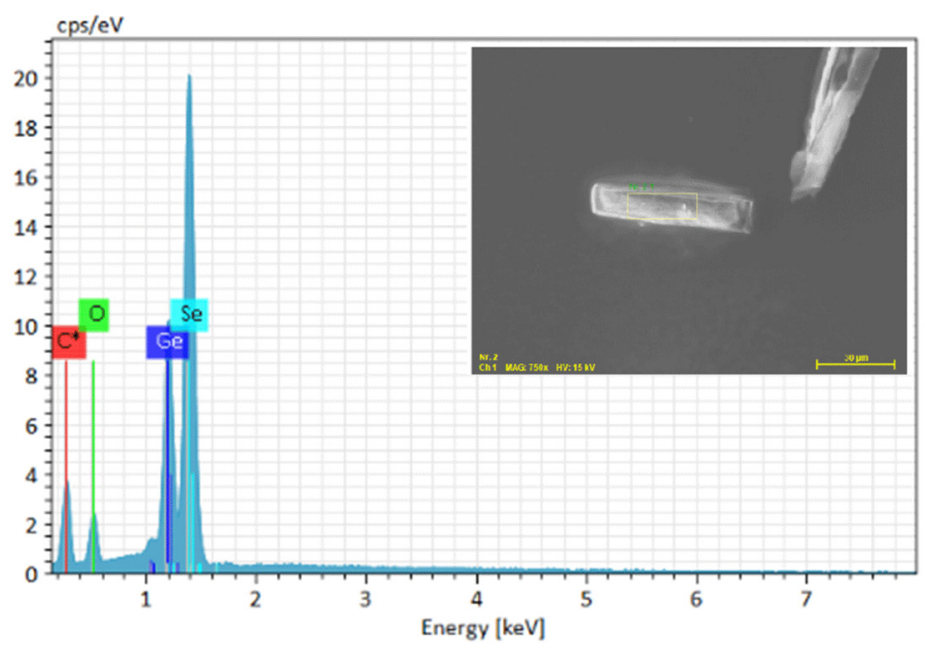

Figure S12. Top: SEM image and EDX spectrum of compound 2a. Bottom: result of the EDX analysis of compound 2a. Slight differences between calculated and simulated results (well below \pm 1 atom) are caused by the overlap of Ge and Se signals in the EDX spectra.

Table S8. Results of the EDX measurement of compound 2a.

\begin{tabular}{llllllll}
\hline Element & $\begin{array}{l}\text { Atomic } \\
\text { No. }\end{array}$ & Netto & $\begin{array}{l}\text { Mass } \\
{[\%]}\end{array}$ & $\begin{array}{l}\text { Atom Cont. } \\
\text { Obs. [\%] }\end{array}$ & $\begin{array}{l}\text { Atom Cont. } \\
\text { Calc. [\%] }\end{array}$ & $\begin{array}{l}\text { Abs. Error } \\
(1 \sigma[w t \%])\end{array}$ & $\begin{array}{l}\text { Rel. Error } \\
(1 \sigma[w t \%])\end{array}$ \\
\hline $\mathrm{Ge}$ & 32 & 30828 & 24.35 & 25.93 & 29.62 & 0.78 & 3.20 \\
\hline $\mathrm{Se}$ & 34 & 85196 & 75.65 & 74.07 & 70.38 & 2.67 & 3.53 \\
\hline
\end{tabular}




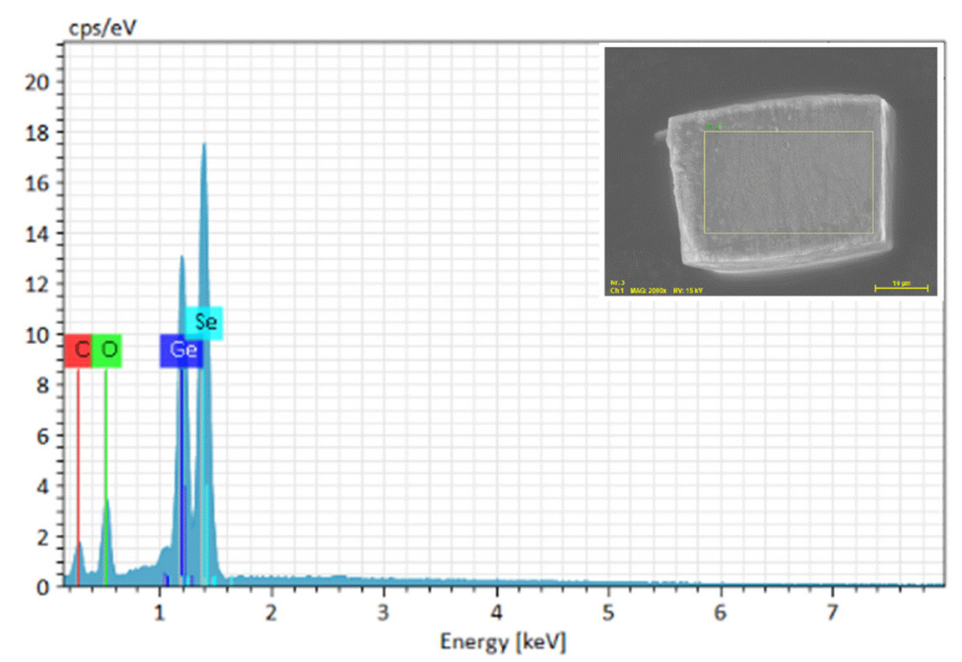

Figure S13. Top: SEM image and EDX spectrum of compound 3. Bottom: result of the EDX analysis of compound 3. Slight differences between calculated and simulated results (well below \pm 1 atom) are caused by the overlap of Ge and Se signals in the EDX spectra.

Table S9. Results of the EDX measurement of compound 3.

\begin{tabular}{llllllll}
\hline Element & $\begin{array}{l}\text { Atomic } \\
\text { No. }\end{array}$ & Netto & $\begin{array}{l}\text { Mass } \\
{[\%]}\end{array}$ & $\begin{array}{l}\text { Atom Cont. } \\
\text { Obs. [\%] }\end{array}$ & $\begin{array}{l}\text { Atom Cont. } \\
\text { Calc. [\%] }\end{array}$ & $\begin{array}{l}\text { Abs. Error } \\
(1 \sigma[w t \%])\end{array}$ & $\begin{array}{l}\text { Rel. Error } \\
(1 \sigma[w t \%])\end{array}$ \\
\hline $\mathrm{Ge}$ & 32 & 43896 & 31.79 & 33.64 & 30.77 & 1.00 & 3.16 \\
\hline $\mathrm{Se}$ & 34 & 76194 & 68.21 & 66.36 & 69.23 & 2.51 & 3.68 \\
\hline
\end{tabular}

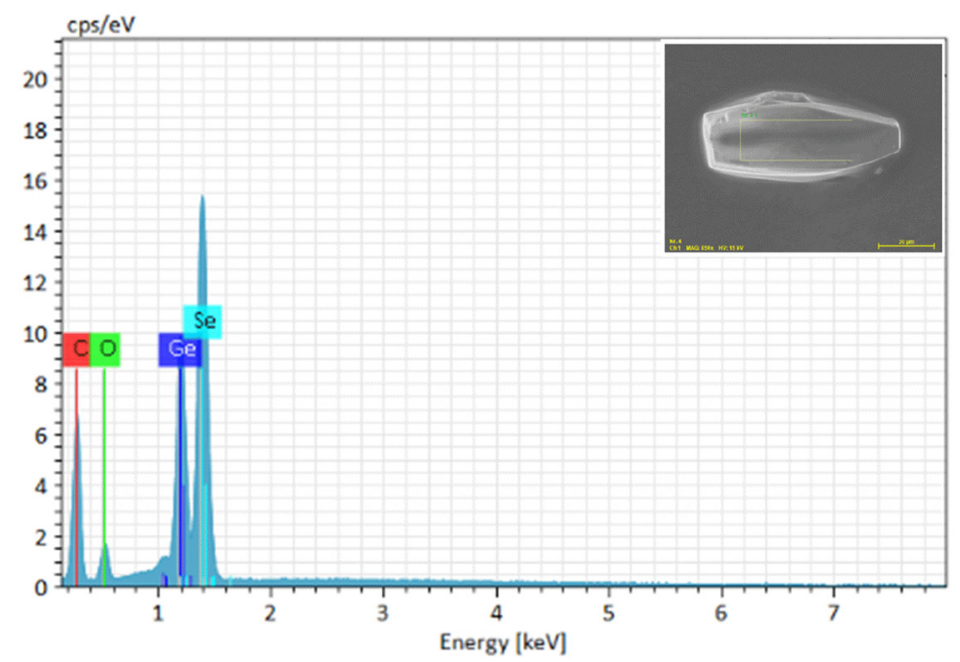

Figure S14. Top: SEM image and EDX spectrum of compound 4. Bottom: result of the EDX analysis of compound 4. Slight differences between calculated and simulated results (well below \pm 1 atom) are caused by the overlap of Ge and Se signals in the EDX spectra.

Table S10. Results of the EDX measurement of compound 4.

\begin{tabular}{llllllll}
\hline Element & $\begin{array}{l}\text { Atomic } \\
\text { No. }\end{array}$ & Netto & $\begin{array}{l}\text { Mass } \\
{[\%]}\end{array}$ & $\begin{array}{l}\text { Atom Cont. } \\
\text { Obs. [\%] }\end{array}$ & $\begin{array}{l}\text { Atom Cont. } \\
\text { Calc. [\%] }\end{array}$ & $\begin{array}{l}\text { Abs. Error } \\
(1 \sigma[\mathrm{wt} \%])\end{array}$ & $\begin{array}{l}\text { Rel. Error } \\
(1 \sigma[\mathrm{wt} \%])\end{array}$ \\
\hline $\mathrm{Ge}$ & 32 & 31528 & 28.58 & 30.32 & 30.77 & 0.91 & 3.19 \\
\hline $\mathrm{Se}$ & 34 & 66259 & 71.42 & 69.68 & 69.23 & 2.59 & 3.62 \\
\hline
\end{tabular}




\section{Electrospray Ionization Mass Spectrometry (ESI-MS)}

\section{ESI Mass Spectra of Compound 1}

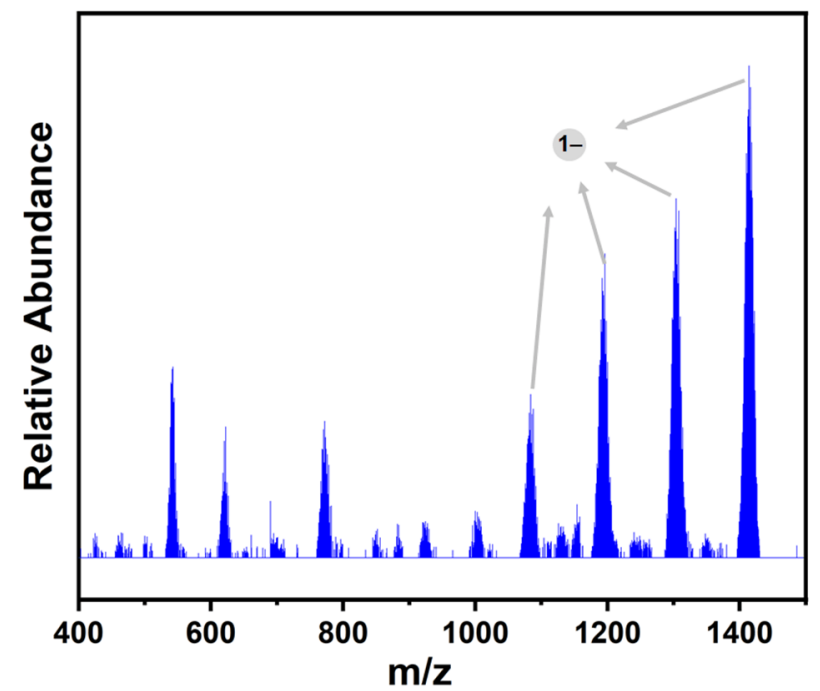

Figure S15. Overview of the ESI(-) mass spectrum of a fresh solution of single-crystals of compound 1 in DMF. The cluster anion was detected with a 1-charge upon assembly with counterions $\left(\mathrm{C}_{2} \mathrm{C}_{1} \mathrm{Im}\right)^{+}$and $\mathrm{H}^{+}$. High-resolution spectra are shown in Figure S16.
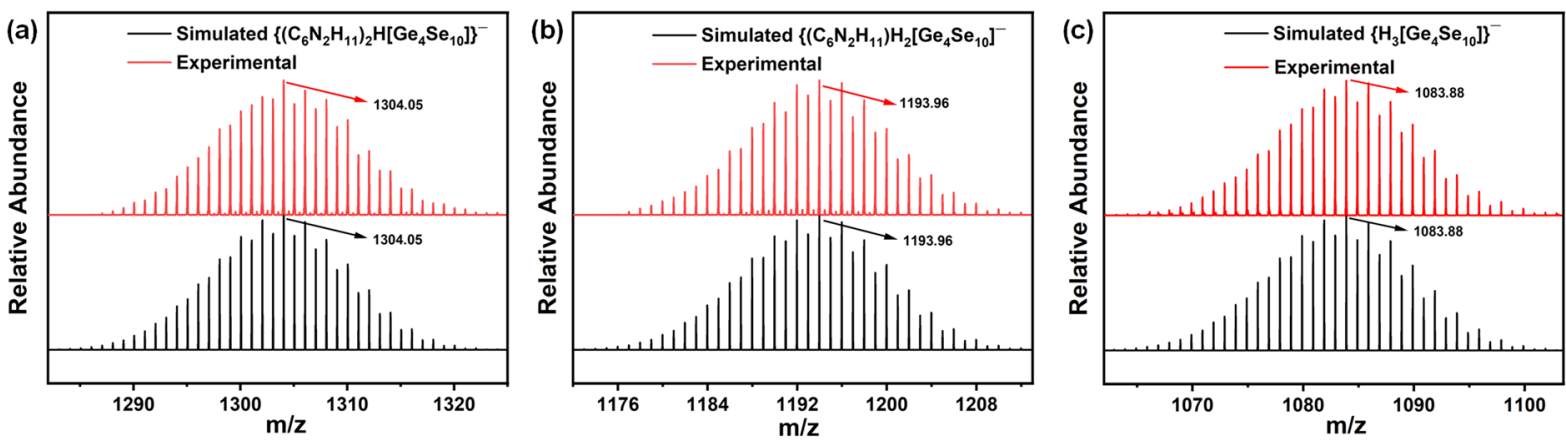

Figure S16. High-resolution mass peak of the cluster anions of 1, detected along with (a) two ionic liquid counterions and one proton, (b) one ionic liquid counterion and two protons, and (c) three protons.

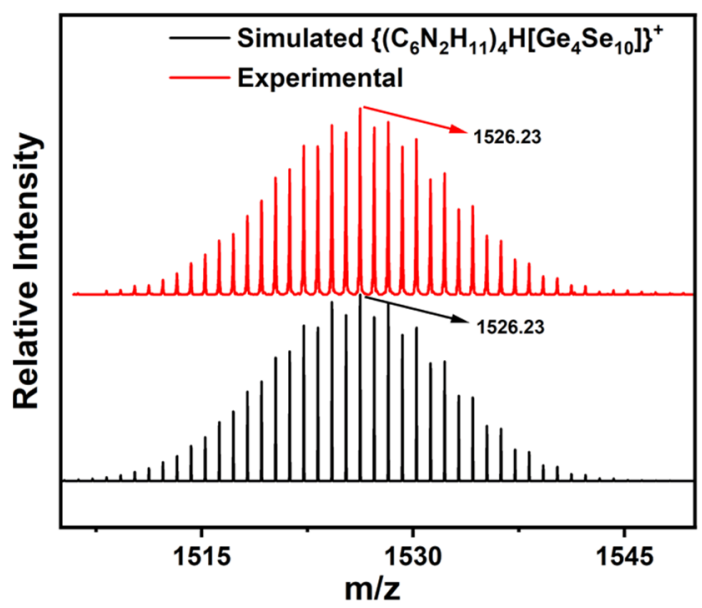

Figure S17. High-resolution ESI $(+)$ mass peak of the cluster anion in 1, detected along with four ionic liquid counterions and one proton. 


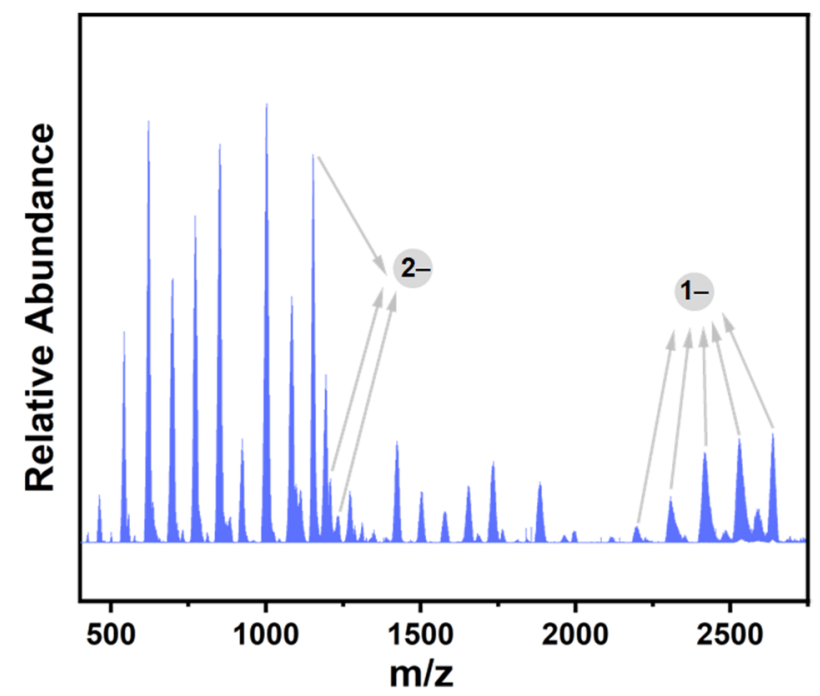

Figure S18. Overview of the ESI(-) mass spectrum of a fresh solution of single-crystal of compound 2a in DMF. The cluster anion was detected with 1- and 2- charges upon assembly with counterions $\left(\mathrm{C}_{2} \mathrm{C}_{1} \mathrm{Im}\right)^{+}$and $\mathrm{H}^{+}$. High-resolution spectra are shown in Figures $\mathbf{S 1 9}$ and S20.
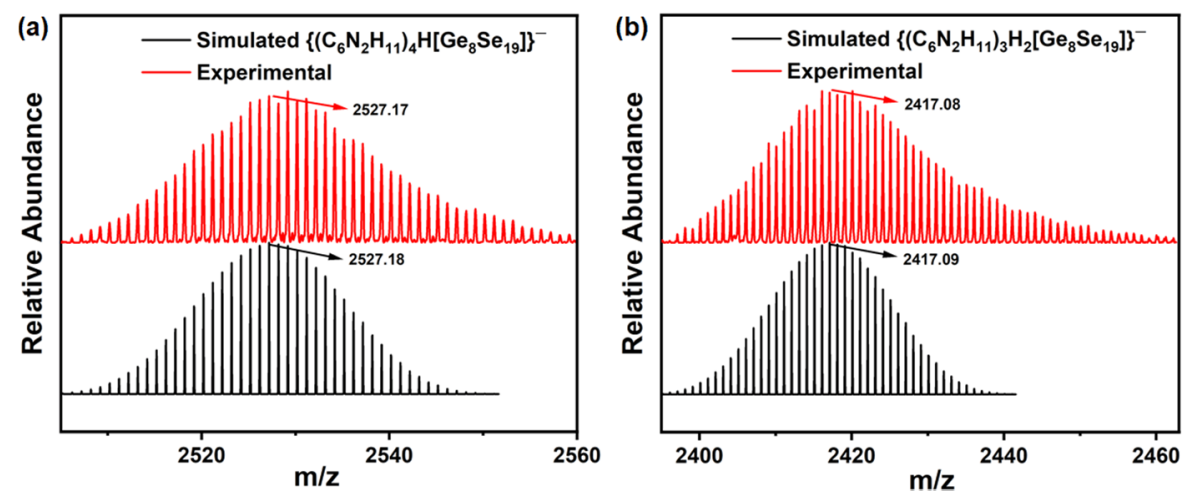

Figure S19. High-resolution mass peak of the cluster anion in $\mathbf{2 a}$, detected along with (a) four ionic liquid counterions and one proton and (b) three ionic liquid counterions and two protons. The "tails" of the experimental signals towards higher $\mathrm{m} / \mathrm{z}$ values indicate overlays with at least two further species that could not be identified yet.
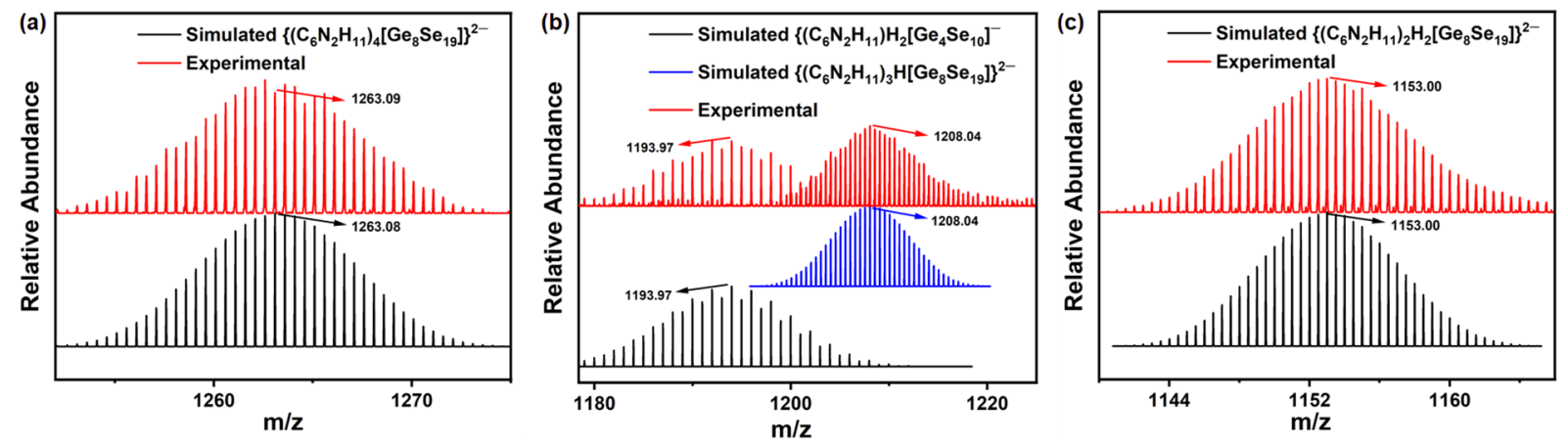

Figure S20. High-resolution mass peak of the cluster anion in $\mathbf{2 a}$, detected along with (a) four ionic liquid counterions, (b) three ionic liquid counterions and one proton, and (c) two ionic liquid counterions and two protons. The isotope pattern shown in (b) results from an overlay of the mass peak of $\left\{\left(\mathrm{C}_{6} \mathrm{~N}_{2} \mathrm{H}_{11}\right)_{3} \mathrm{H}\left[\mathrm{Ge}_{8} \mathrm{Se}_{19}\right]\right\}^{2-}$ with that of the fragment $\left\{\left(\mathrm{C}_{6} \mathrm{~N}_{2} \mathrm{H}_{11}\right) \mathrm{H}_{2}\left[\mathrm{Ge}_{4} \mathrm{Se}_{10}\right]\right\}^{-}$ formed during the ionization process. 


\section{ESI mass spectra of compound 3}

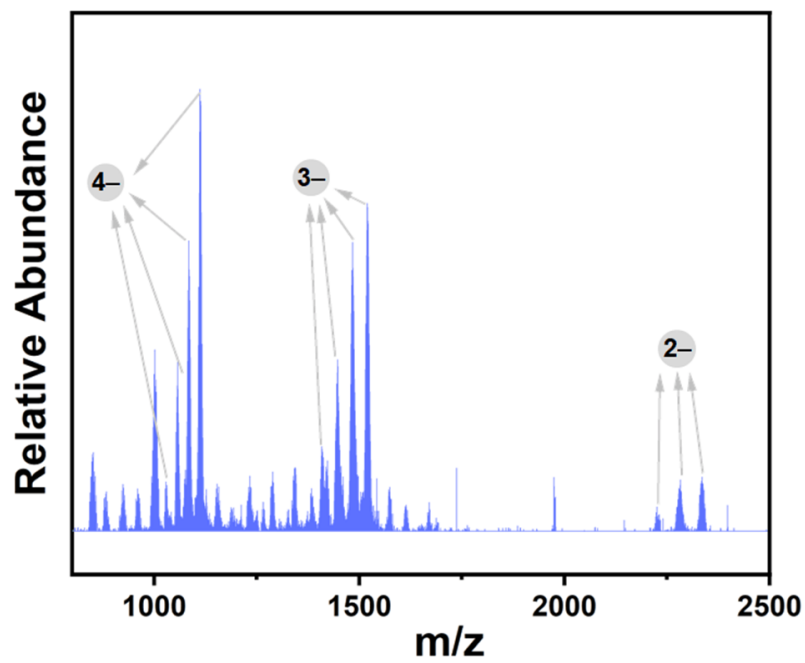

Figure S21. Overview of the ESI(-) mass spectrum of a fresh solution of single-crystal of compound 3 in DMF. The cluster anion was detected with 1- and 2- charges upon assembly with counterions $\left(\mathrm{C}_{2} \mathrm{C}_{1} \mathrm{Im}\right)^{+}$and $\mathrm{H}^{+}$. High-resolution spectra are given in Figures $\mathbf{S 2 2}-\mathbf{S 2 4}$.
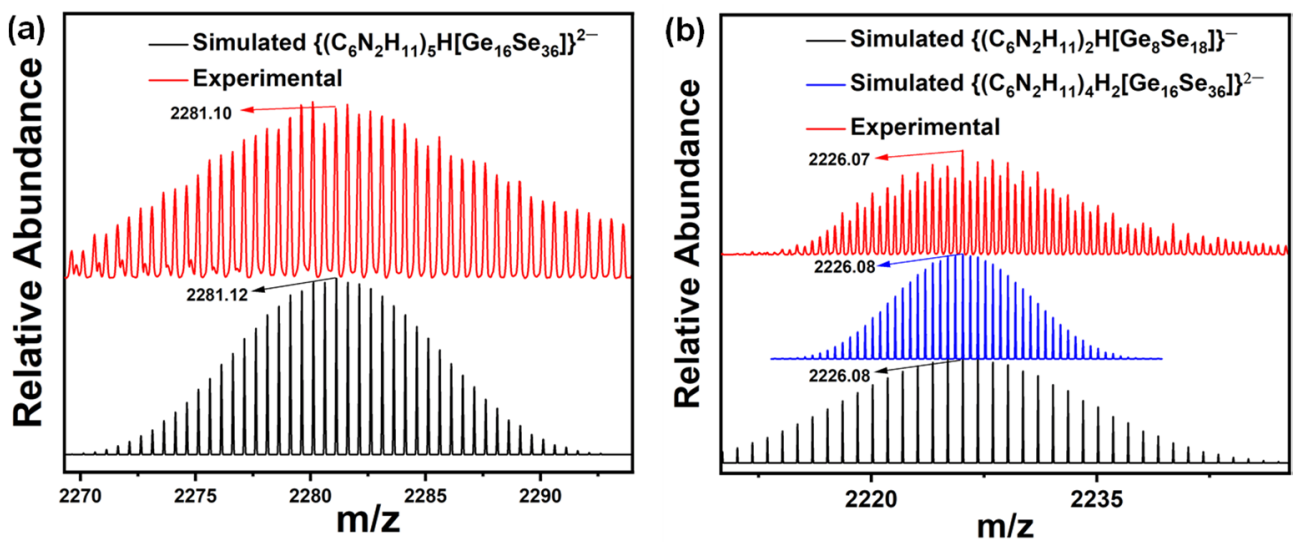

Figure S22. High-resolution mass peak of the cluster anions in 3, detected along with (a) five ionic liquid counterions and one proton and (b) four ionic liquid counterions and two protons. The isotope pattern shown in (c) results from an overlay of the mass peak of $\left\{\left(\mathrm{C}_{6} \mathrm{~N}_{2} \mathrm{H}_{11}\right)_{4} \mathrm{H}_{2}\left[\mathrm{Ge}_{16} \mathrm{Se}_{36}\right]\right\}^{2-}$ with that of the fragment $\left\{\left(\mathrm{C}_{6} \mathrm{~N}_{2} \mathrm{H}_{11}\right)_{2} \mathrm{H}\left[\mathrm{Ge}_{8} \mathrm{Se}_{18}\right]\right\}^{-}$formed during the ionization process. The "tail" of the signal shown in (b) towards higher $\mathrm{m} / \mathrm{z}$ values indicate overlays with at least one more species that could not be identified yet. 

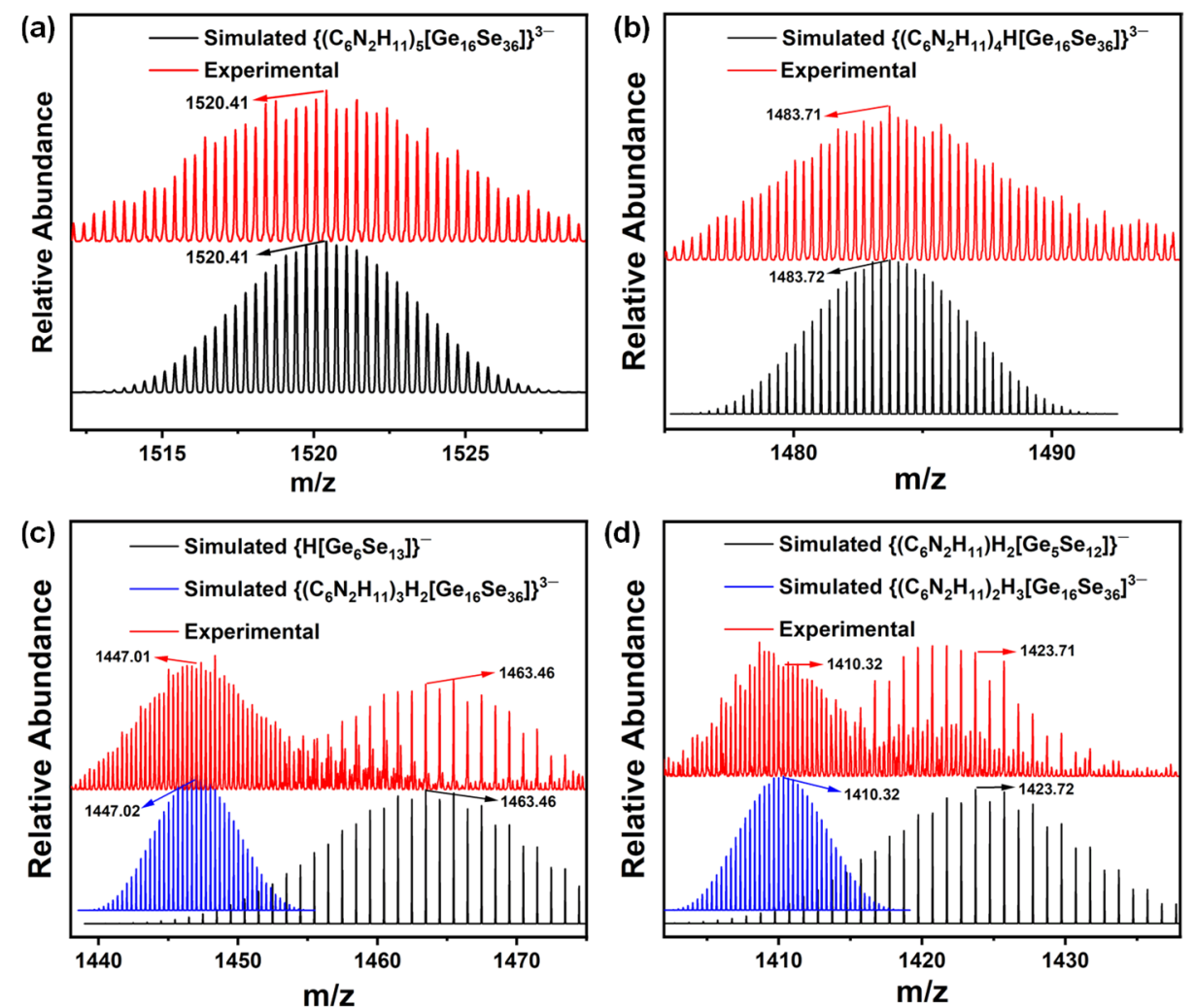

Figure S23. High-resolution mass peak of the cluster anion in $\mathbf{3}$ with (a) five ionic liquid counterions; (b) four ionic liquid counterions and one proton; (c) three ionic liquid counterions and two protons; (d) two ionic liquid counterions and three protons. The isotope patterns shown in (c) and (d) result from an overlay of the mass peak of $\left\{\left(\mathrm{C}_{6} \mathrm{~N}_{2} \mathrm{H}_{11}\right)_{3} \mathrm{H}_{2}\left[\mathrm{Ge}_{16} \mathrm{Se}_{36}\right]\right\}^{3-}$ with that of the fragment $\left\{\mathrm{H}\left[\mathrm{Ge}_{6} \mathrm{Se}_{13}\right]\right\}^{-}$, and from an overlay of the mass peak of $\left\{\left(\mathrm{C}_{6} \mathrm{~N}_{2} \mathrm{H}_{11}\right)_{2} \mathrm{H}_{3}\left[\mathrm{Ge}_{16} \mathrm{Se}_{36}\right]\right\}^{3-}$ with that of the fragment $\left\{\left(\mathrm{C}_{6} \mathrm{~N}_{2} \mathrm{H}_{11}\right) \mathrm{H}_{2}\left[\mathrm{Ge}_{5} \mathrm{Se}_{12}\right]\right\}^{-}$, respectively, formed during the ionization process.
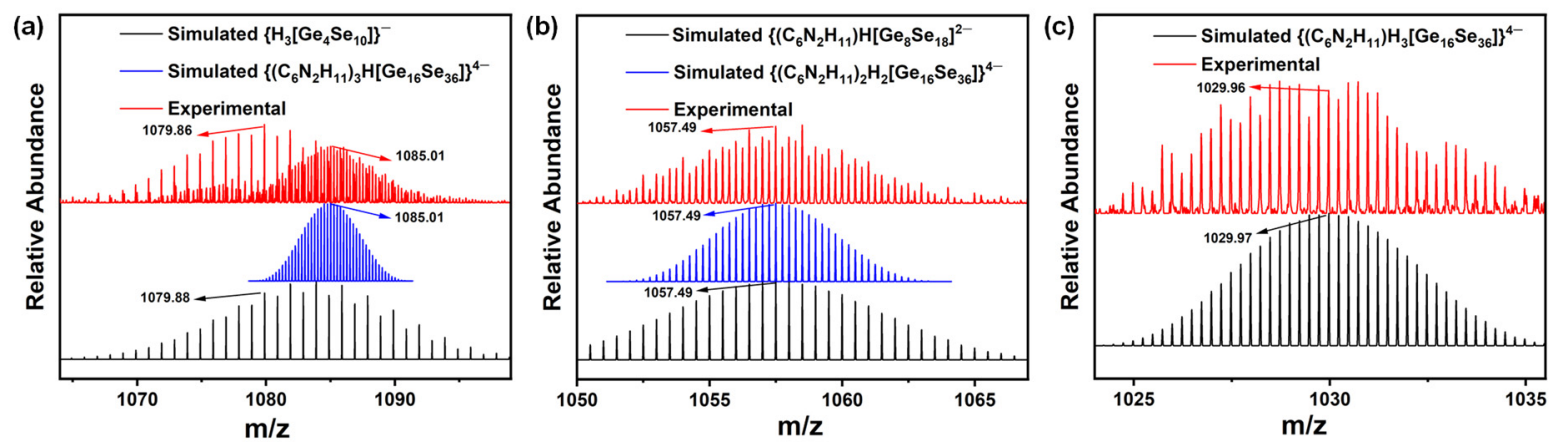

Figure S24. High-resolution mass peak of the cluster anion in $\mathbf{3}$ with (a) three ionic liquid counterions and one proton; (b) two ionic liquid counterions and two proton; (c) one ionic liquid counterion and three protons. The isotope patterns shown in (a) and (b) result from an overlay of the mass peak of $\left\{\left(\mathrm{C}_{6} \mathrm{~N}_{2} \mathrm{H}_{11}\right)_{3} \mathrm{H}\left[\mathrm{Ge}_{16} \mathrm{Se}_{36}\right]\right\}^{4-}$ with that of the fragment $\left\{\mathrm{H}_{3}\left[\mathrm{Ge}_{4} \mathrm{Se}_{10}\right]\right\}^{-}$, and from an overlay of the mass peak of $\left\{\left(\mathrm{C}_{6} \mathrm{~N}_{2} \mathrm{H}_{11}\right)_{2} \mathrm{H}_{2}\left[\mathrm{Ge}_{16} \mathrm{Se}_{36}\right]\right\}^{3-}$ with that of the fragment $\left\{\left(\mathrm{C}_{6} \mathrm{~N}_{2} \mathrm{H}_{11}\right) \mathrm{H}\left[\mathrm{Ge}_{8} \mathrm{Se}_{18}\right]\right\}^{-}$, respectively, formed during the ionization process. 

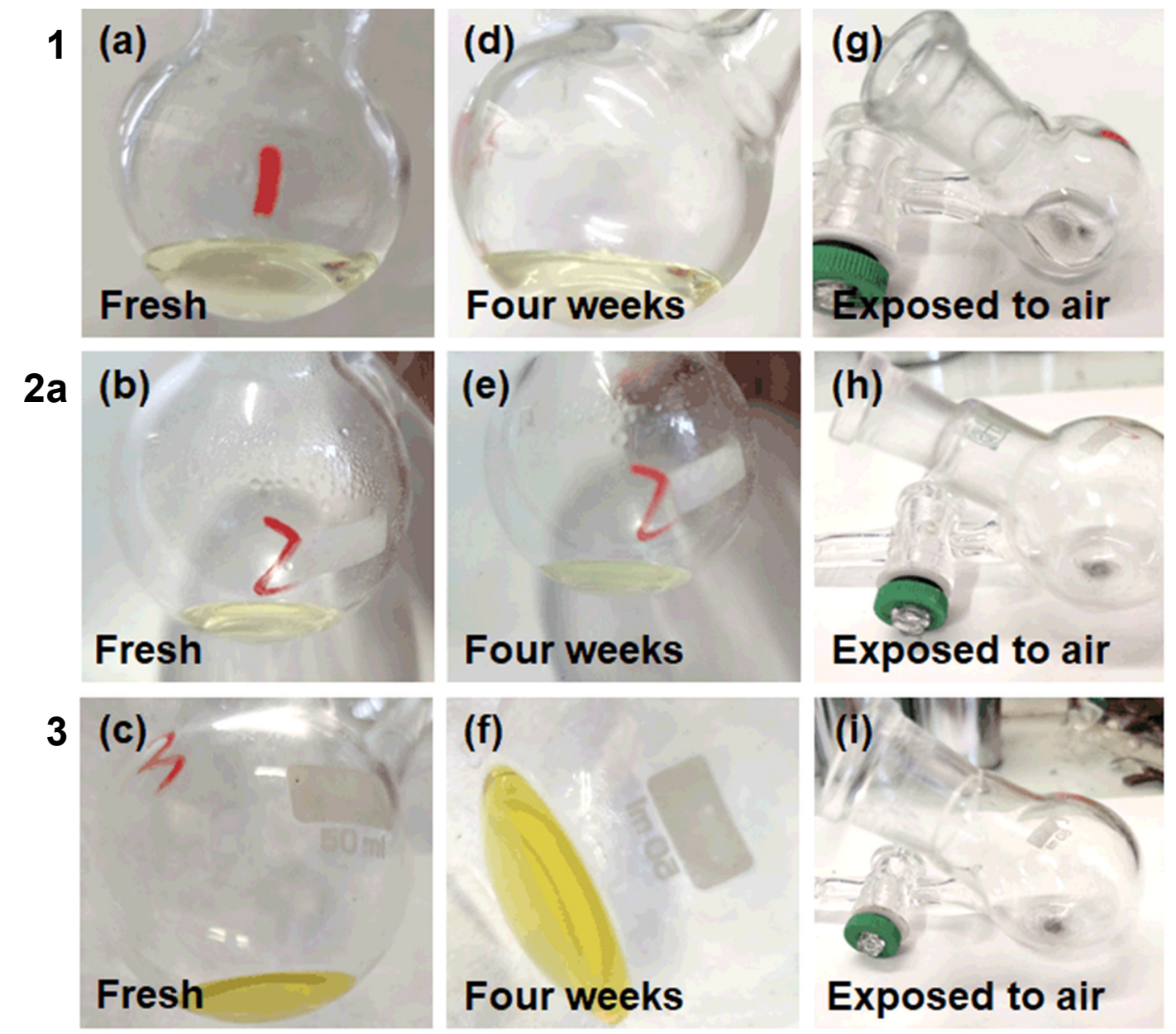

Figure S25. Photographs of fresh solutions of compound 1 (a), compound 2a (b), and compound 3 (c) dissolved in DMF under inert conditions. Photographs of DMF solutions of compound $\mathbf{1}$ (d), compound $\mathbf{2 a}$ (e), and compound $\mathbf{3}$ (f) after being kept under inert condition for four weeks. Photographs of DMF solutions of compound 1 (g), compound 2a (h), and compound 3 (i) after being exposed to air for two hours. Corresponding experiments of compounds $\mathbf{2 b}$ and $\mathbf{4}$ were impossible owing to the small yield of compound $\mathbf{2 b}$ on the one hand, and the insolubility of the extended-network compound 4 on the other hand. 

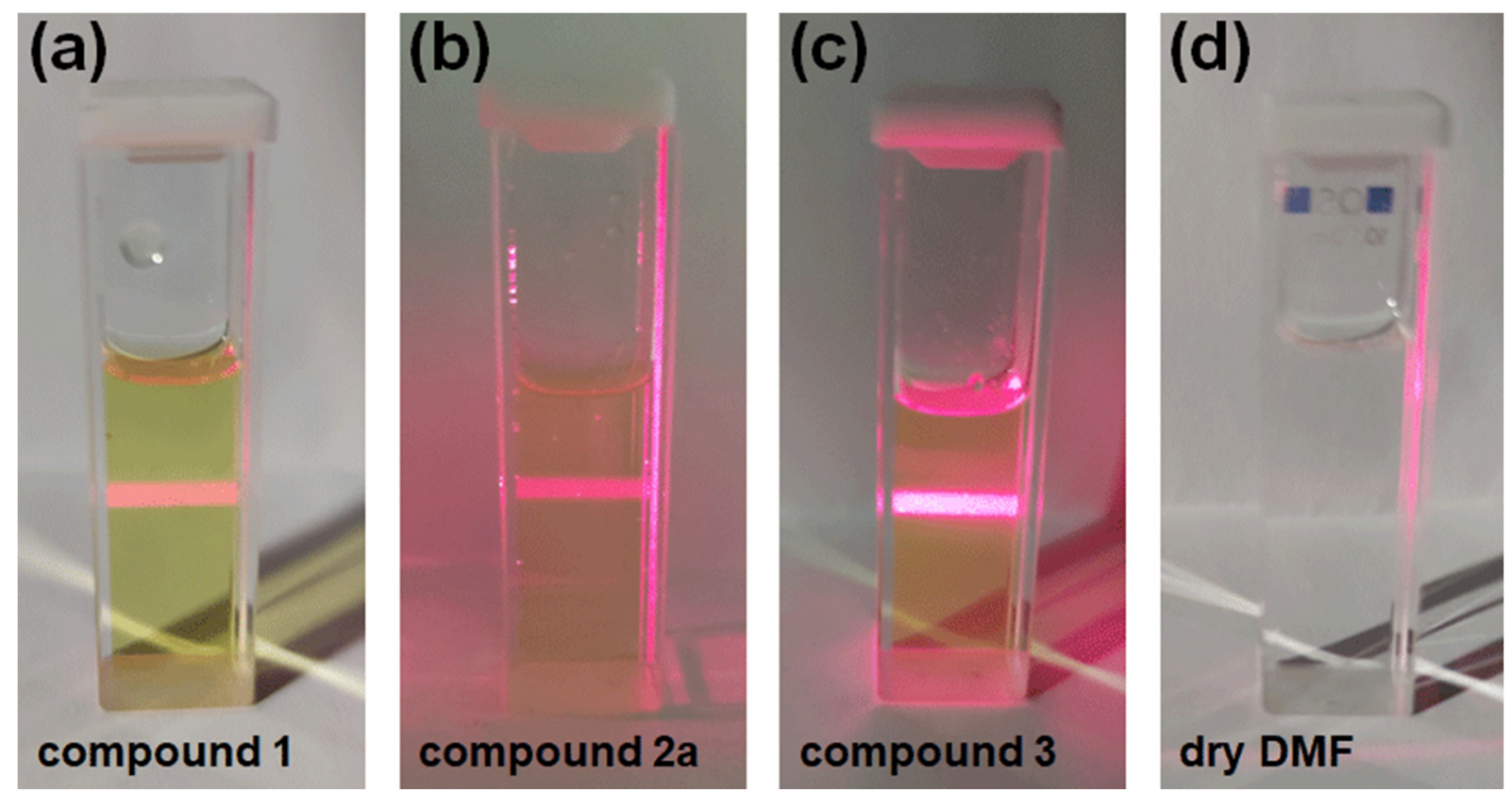

Figure S26. Illustration of the Tyndall effect to occur in solutions of compounds $\mathbf{1}, \mathbf{2 a}$, and $\mathbf{3}$, as illustrated in Figure S26 (with pure DMF as a reference, right). The nano-particular size of the solute could be confirmed - in agreement with the dynamic light scattering experiments (see Section 9). 


\section{Dynamic Light Scattering (DLS)}
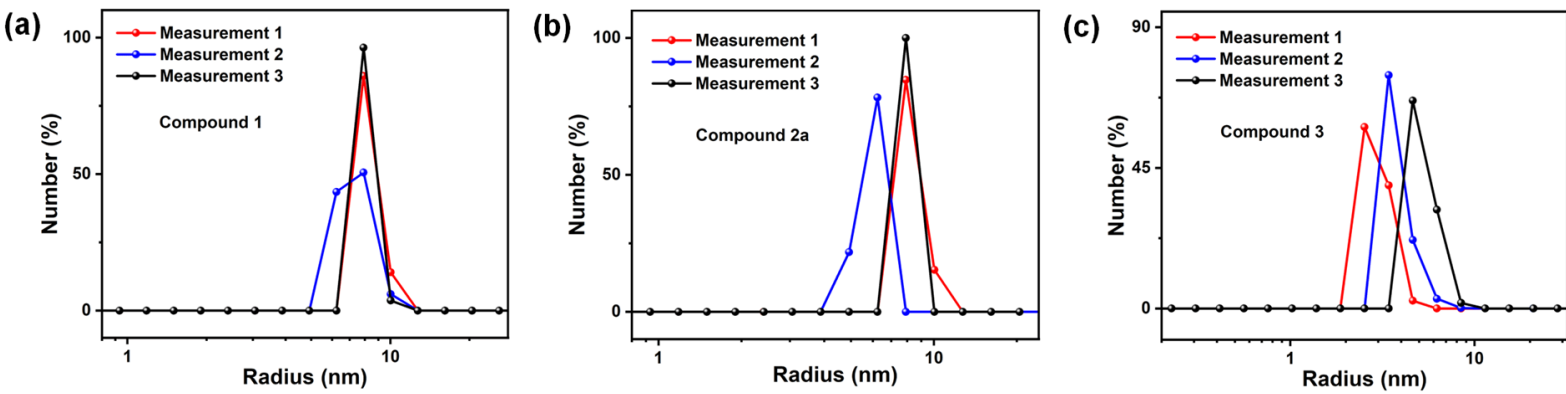

Figure S27. DLS measurements of fresh solutions of compounds 1 (a), compound $\mathbf{2 a}$ (b), and compound $\mathbf{3}$ (c) in DMF. Corresponding experiments of compound $\mathbf{2 b}$ were hampered by the small yield of this compound. Corresponding results are given in Table S11.

Table S11. Summary of the hydrodynamic radii $\left(R_{\mathrm{H}}\right)$ and polydispersity according to DLS measurements on fresh solutions of compounds 1, 2a, and $\mathbf{3}$ in DMF.

\begin{tabular}{lllll}
\hline Compound & $R_{\mathrm{H}}[\mathrm{nm}]$ & $\begin{array}{l}R_{\mathrm{H}}[\mathrm{nm}] \\
\text { (mean value) }\end{array}$ & Polydispersity [\%] & $\begin{array}{l}\text { Polydispersity [\%] } \\
\text { (mean value) }\end{array}$ \\
\hline $\mathbf{1}$ & $8.31 / 7.31 / 7.99$ & 7.87 & $9.99 / 14.52 / 5.01$ & 9.84 \\
\hline $\mathbf{2 a}$ & $8.23 / 5.95 / 7.91$ & 7.36 & $9.27 / 9.15 / 11.06$ & 9.83 \\
\hline $\mathbf{3}$ & $2.93 / 3.78 / 5.20$ & 3.97 & $17.39 / 18.47 / 16.76$ & 17.54 \\
\hline
\end{tabular}
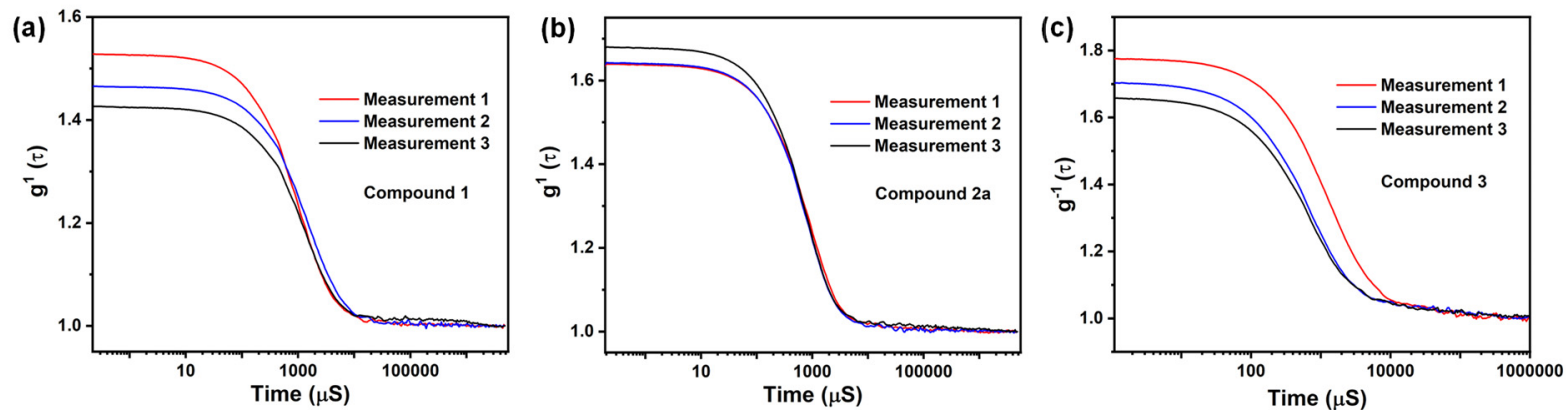

Figure S28. Autocorrelation function generated from fresh solutions of compounds 1 (a), compound 2a (b), and compound 3 (c) in DMF. Corresponding experiments of compound $\mathbf{2 b}$ were hampered by the small yield of this compound. 


\section{Raman and Optical Absorption Spectroscopy}

\section{Raman Spectra of Compounds 1, 2a, 3, and 4}

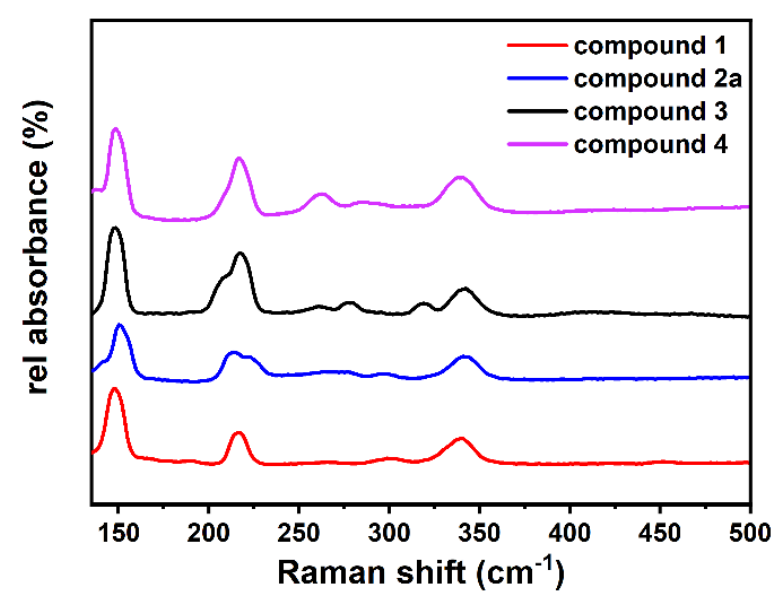

Figure S29. Raman spectra of compounds 1, 2a, 3 and 4. The peaks at $145 \mathrm{~cm}^{-1}$ and $339 \mathrm{~cm}^{-1}$ are signed to the stretching modes of Ge-Se bonds. ${ }^{2-5}$ The peaks at $217 \mathrm{~cm}^{-1}$ are attributed to the symmetric stretching mode of the $\left[\mathrm{GeSe}_{4}\right]^{4-}$ tetrahedron. ${ }^{6}$ Corresponding experiments of compound $\mathbf{2} \mathbf{b}$ were hampered by the small yield of this compound.

\section{UV-Visible Diffuse-Reflectance Spectra of Compounds 1, 2a, 3, and 4}
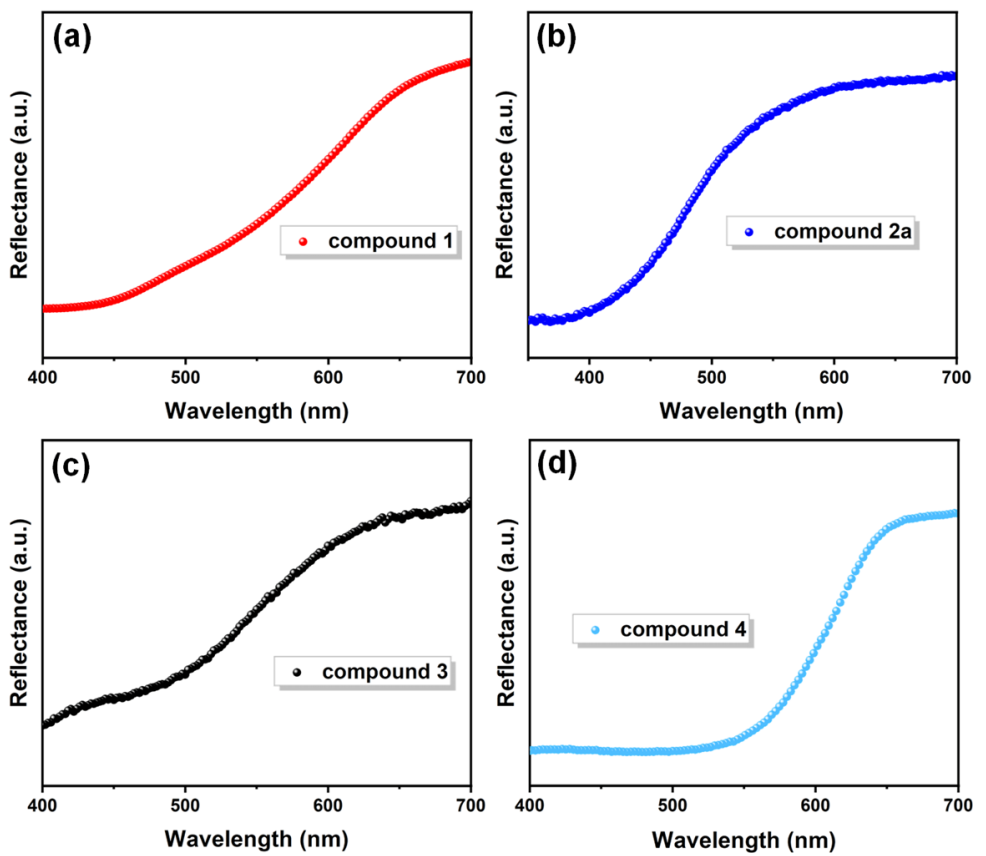

Figure S30. Solid-state UV-visible spectra of single-crystalline samples of 1 (a), 2 a (b), 3 (c) and $4(d)$, recorded in diffuse-reflectance mode. Corresponding experiments of compound $\mathbf{2 b}$ were hampered by the small yield of this compound. 


\section{References for the Supporting Information}

1 Spek, A. L. PLATON SQUEEZE: a tool for the calculation of the disordered solvent contribution to the calculated structure factors. Acta Crystallogr. Sect. C Struct. Chem. 2015, $71,9-18$.

2 Choudhury, A.; Strobel, S.; Martin, B. R.; Karst, A. L.; Dorhout, P. K., Synthesis of a Family of Solids through the Building-Block Approach: A Case Study with $\mathrm{Ag}^{+}$Substitution in the Ternary Na-Ge-Se System. Inorg. Chem. 2007, 46, 2017-2027.

3 Martin, B. R.; Polyakova, L. A.; Dorhout, P. K., Synthesis and Characterization of a Family of Two Related Quaternary Selenides: $\mathrm{Na}_{8} \mathrm{Eu}_{2}\left(\mathrm{Si}_{2} \mathrm{Se}_{6}\right)_{2}$ and $\mathrm{Na}_{9} \mathrm{Sm}\left(\mathrm{Ge}_{2} \mathrm{Se}_{6}\right)_{2}$. J. Alloys Compd. 2006, 408-412, 490-495.

4 Ma, N.; Xiong, L.; Chen, L.; Wu, L.-M., Vibration Uncoupling of Germanium with Different Valence States Lowers Thermal Conductivity of $\mathrm{Cs}_{2} \mathrm{Ge}_{3} \mathrm{Ga}_{6} \mathrm{Se}_{14}$. Sci. China Mater. 2019, 62, 1788-1797.

5 Csarnovics, I.; Veres, M.; Nemec, P.; Molnár, S.; Kökényesi, S., Surface Plasmon Enhanced Light-induced Changes in GeSe Amorphous Chalcogenide - Gold Nanostructures. J. Non Cryst. Solids 2020, 6, 100045.

6 Evenson; Dorhout, P. K., Synthesis and Characterization of Four New Europium Group XIV Chalcogenides: $\mathrm{K}_{2}$ EuTSe$_{5}$ and $\mathrm{KEuTS}_{4}(\mathrm{~T}=\mathrm{Si}, \mathrm{Ge})$. Inorg. Chem. 2001, 40, 2409-2414. 